\title{
Wolność absurdalna a odpowiedzialność w filozofii Alberta Camusa
}

\section{Absurd Freedom and responsibility in Albert Camus philosophy}

\section{Streszczenie:}

Artykuł odnosi się do elementów filozofii Alberta Camusa. W szczególności rozważa kwestię „wolności absurdalnej”, skupiając się na niej w kontekście jej relacji do pojęcia odpowiedzialności. Wskazuje znaczenie relacji człowiek-człowiek, jako kontrast dla relacji człowiek-świat. Autor ostatecznie dowodzi, że „wolność absurdalna” nie stoi w sprzeczności w odpowiedzialnością, a może być jednym z jej warunków.

Słowa kluczowe: wolność, odpowiedzialność, człowiek, absurd

\section{Abstract:}

The article refers to the elements of the philosophy of Albert Camus. In particular its considering the matters of "absurd freedom”. Especially it focus on the context of responsibility. It shows importance of person-person relation, as the contrast to the person-world relation. The author finally reveals that "absurd freedom” is not contradictory with responsibility however it could be one of the required conditions.

Keywords: freedom, responsibility, human, absurd

\section{Wstęp}

Odpowiedzialność i wolność to terminy bardzo istotne dla filozofii egzystencjalnej. W niniejszym tekście podjąłem ich problematykę poprzez pryzmat twórczości jednego z przedstawicieli tejże filozofii Alberta Camusa. Jako że sam filozof w ciągu swojego życia zmienił 
Rafał Materek - Wolność absurdalna a odpowiedzialność...

podejście co do zasad, na jakich owe terminy powinny funkcjonować, chciałbym się skupić na jego pierwotnej koncepcji wolności - wolności absurdalnej. Podstawowe pytania, na jakie należy zwrócić uwagę, dotyczą relacji między wolnością a odpowiedzialnością, samym rozumieniem wolności i problemami, jakie wiążą się z różnymi jej rodzajami, a także granic i zakresu odpowiedzialności oraz możliwości jej rozumienia. Uwagę zwraca też fundamentalna różnica, jaka charakteryzuje pojęcie odpowiedzialności u różnych przedstawicieli filozofii egzystencjalnej. Rozciąga się ona od odpowiedzialności całkowitej u Sartre'a do częściowej niewinności u Camusa.

Niewątpliwie ważne jest tu pewne tło kulturowe. Europa, jako miejsce nieustannych walk między ideami, wielu koncepcji filozoficznych. Miejsce wielu sprzeczności i stawiania spraw na ostrzu noża. Zauważa to już Karl Jaspers w swoim tekście „O źródle i celu historii”, by dalej rozpoznać Europę jako kolebkę demokracji:

W Grecji wyrosła, nawet jeśli tylko przejściowo, wolność, która nigdzie dotąd nie powstała. Braterska przysięga wolnych ludzi przeforsowuje przeciw uniwersalnemu despotyzmowi narodu uszczęśliwiającą organizację totalną. Wraz z tym polis staje się podstawą całej zachodniej świadomości wolności, zarazem rzeczywistości wolności, jak i myślenia o wolności ${ }^{1}$.

Demokracja jest istotnym powodem, dla którego i dzięki któremu podejmujemy refleksję nad relacją wolności i odpowiedzialności. Są to więc dociekania szczególnie ważne dla funkcjonowania europejskiej rzeczywistości fundowanej na idei równości i wolności.

Nie tylko płaszczyzna geograficzna wyznacza pewne zależności, także w kontekście czasu pojawiają się pewne istotne zjawiska, które dodatkowo korespondują z wizją człowieka, jaką prezentuje Camus. Na myśli mam tu przede wszystkim wzrastającą prędkość życia oraz częstotliwość zmian, charakterystyczne dla życia współczesnego Europejczyka. Camusowska koncepcja staje naprzeciw wyzwaniom czasu, nie starając się jedynie zakamuflować problemu. Nie znajdziemy tu próby pogodzenia zmienności i stabilizacji. Człowiek pozba-

\footnotetext{
${ }^{1}$ K. Jaspers, O źródle i celu historii, Kęty 2006, s. 68.
} 
wiony będzie oparcia od początku do końca. Jakkolwiek wydawać by się mogło, iż to propozycja niezwykle pesymistyczna, ostateczna ocena może nie być tak jednoznaczna. Próba oszacowania atrakcyjności rozwiązań, jakie proponuje autor Mitu Syzyfa, jest sprawą drugorzędną wobec ich przystawania do rzeczywistości oraz zdolności do neutralizacji problemów, z jakimi zmaga się współczesny człowiek. Owo przystawanie do rzeczywistości, z uwagi na zbieżność zjawisk, jakie zauważał Camus oraz tych, które obserwujemy wokół siebie, zdaje się być faktem. Nie ma w tym nic zaskakującego, jeśli wziąć pod uwagę, że ogromną inspiracją Camusa była myśl Nietschego. Myśl, która nosi w sobie wiele znamion bycia wizjonerską w kontekście zmian zachodzących na starym kontynencie.

\section{Specyfika koncepcji człowieka absurdalnego}

Znamienną cechą człowieka absurdalnego jest bunt. To on jest tym, co powoduje walkę człowieka z rzeczywistością wokół niego. Nieustanne podawanie $\mathrm{w}$ wątpliwość świata, uparte dążenie, by być ciągle w pełni obecnym. Bunt to czynnik, który pojawia się jako alternatywa samobójstwa; gdy pojawia się absurd, człowiek godzi się nań, wtedy to właśnie bunt pozwala mu na trwałe podtrzymywanie aktualnego stanu. Nie ma on jednak charakteru ciągłego, raczej pojawia się $\mathrm{w}$ każdej sytuacji na nowo, na nowo dając okazję do mierzenia się ze światem. „Bunt nie jest dążeniem, nie zna nadziei. To pewność druzgocącego losu, ale bez rezygnacji"2. Widać tu dokładnie, jak Camus stawia naprzeciw siebie życie absurdalne oraz samobójstwo, które określa jako rezygnację. Odebranie sobie życia porównuje do wszelkich innych sposobów unicestwienia absurdu. Tak, jak każdy inny „skok”, samobójstwo niszczy jeden z podstawowych członów niezbędnych do trwania w tym metafizycznym rozdźwięku. Jest ono pogodzeniem się ze skończonością swego życia i zrozumieniem jego bezsensowności wobec wieczności nieistnienia. Człowiek, który tak czyni,

\footnotetext{
2 A. Camus, Mit Syzyfa, Warszawa, 2001, s. 48.
} 
Rafał Materek - Wolność absurdalna a odpowiedzialność...

przyśpiesza tylko to, przed czym czuje się bezbronny. Dlatego też potrzeba buntu, który uczy, iż nawet wobec tej miażdżącej świadomości tym, co może nadać wartość życiu, jest permanentna niezgoda między człowiekiem a jego przemijalnością. $W$ tym momencie pojawia się jedno z najważniejszych zdań, znamiennych dla koncepcji Camusa. „Dla człowieka bez klap na oczach nie ma piękniejszego widoku, niż widok inteligencji walczącej z realnością, która ją przekracza"3 $^{3}$ oto, gdzie rozpoznać można wartość życia. Jednym z największych atutów człowieka jest jego wola. Nieograniczona i wynikająca źródłowo z człowieka, jest $\mathrm{w}$ nim czynnikiem nadającym mu nadludzki charakter. Nie posiada granic, stąd też rodzi się jej potęga; pozbawiając człowieka woli, pozbawia się go całej jego wielkości. To dzięki woli człowiek przez wieki przetwarzał rzeczywistość, nie był jej niewolnikiem, lecz panem. Im bardziej była ona wyraźna i silna, tym większych czynów dokonywał. Jeśli inteligencja ludzka nie ma dziś siły, by wygrać z rzeczywistością, to nic innego jak wola umożliwi tę wygraną w przyszłości. Człowiek, który zdaje się na wolę innych, sam pozbawi się swego człowieczeństwa na rzecz pewnej mechaniczności i zdradza swą inteligencję, nie powołując jej do walki, lecz pozostawiając w letargu.

Życie pozbawia się wartości, gdy pozbawia się je ciężaru. Tylko wyraźny problem sprowadza nas do rzeczywistości, rozkazuje nam, byśmy tu i teraz zajęli się nim, grożąc niepowodzeniem lub jakąkolwiek negatywną konsekwencją związaną z naszą pasywnością. Właśnie w momencie walki, poszukiwania rozwiązania, które samo w sobie jest już buntem wobec danego stanu rzeczy, doświadczamy życia najpełniej, jak tylko się da. To te chwile jawią się najsilniej w pamięci, które sprowadzały nas do pewnej granicy, które z największym uporem nie dawały się zignorować. Sytuacje które nie wymagają takiego poświęcenia, umykają naszej uwadze, wraz z nimi chwile w których wystąpiły - i tak przez palce ucieka większość życia człowieka, który nie czyni pożytku ze swej woli. Dlaczego więc wyrzekać się życia?

\footnotetext{
3 Tamże, s. 49.
} 
Z obawy przed odpowiedzialnością i konsekwencją? Czym one są wobec jałowości życia i ostatecznej konsekwencji - nieuchronności śmierci? Jeśli kiedyś zostaniemy pozbawieni życia, czemuż pozbawiać się go już teraz? Ta niekonsekwencja jawi się na każdym kroku, wśród społeczeństw, które przyjmując pewne konwencje, stały się skostniałymi systemami, w których człowiek jest tylko trybem pracującej maszyny.

\section{Oblicza wolności}

U Alberta Camusa wolność stanowi podstawowy czynnik ludzkiego bycia. Podobnie jak u innych przedstawicieli filozofii egzystencji stanowi ona czynnik ukazujący istotną problematyczność egzystencji. Podjęcie ciężaru wolności jest istotną możliwością ludzkiego bycia. $\mathrm{Z}$ jednej strony jej podjęcie jest możliwe, $\mathrm{z}$ drugiej nie jest wyznaczone żadną konkretną racją. W pewnym znaczeniu Camus mógłby powtórzyć za Sartrem, że człowiek skazany jest na wolność. Postawa, która polega na unikaniu tego „wyroku” wolności, określana jest jako ucieczka od niej. W formule tej ucieczki kryje się pewna osobliwość, gdyż trudno wskazać tu jakąś aktywność ze strony człowieka. Można by powiedzieć, że mamy tu do czynienia z brakiem czy też powstrzymaniem się przed takim ruchem. Tak mogłoby to wyglądać na pierwszy rzut oka.

Po dłuższym zastanowieniu kwestia ta wydaje się bardziej złożona. Jak pisze Camus: „To ten śmieszny rozum przeciwstawia mnie światu"4. Odróżniając istotę ludzką od świata zwierzęcego, akcentuje rolę rozumu i z tą aktywnością wiąże pewne specyficzne dla człowieka napięcie. Stąd można by przyjąć, że ów brak ruchu świadomości jest jakąś postacią celowego działania człowieka, który chce pozostawać w swoistym uśpieniu.

Pierwotna wrogość świata idzie ku nam przez tysiąclecia. Przez sekundę nie rozumiemy go już, skoro przez wieki rozumieliśmy z niego tylko kształty

\footnotetext{
4 Tamże, s. 46.
} 
Rafał Materek - Wolność absurdalna a odpowiedzialność...

i linie, które wpierw w nim zawarliśmy, a brak nam teraz sił by korzystać z tej sztuczki ${ }^{5}$.

Bariera, która stoi między człowiekiem a światem, jest rozpoznana u samego początku. Jego samego przeraża obcość świata, gdy cała wiedza, jaką posiada staje się niewystarczająca do zrozumienia jego elementów, jakie mu się jawią. Każde miejsce może mieć swoją tajemnicę, posiadać swoją historię. Poznać ją to mały krok do przodu, doświadczyć owej tajemnicy - znacznie większy. Ale nawet obcowanie z tajemnicą nie zmniejsza dystansu, osłabia i w pewien sposób kruszy mur milczenia oddzielający człowieka od świata. W tej przestrzeni obcowania człowieka ze światem widocznej tylko dla niego samego pojawia się swoista mgła mistyczności. To rodzaj interakcji, który dany jest tylko wewnętrznemu przeżyciu i charakteryzuje się niewyrażalnością. Tajemnica pozwala obcować $\mathrm{z}$ elementem świata, jednocześnie będąc przeszkodą $\mathrm{w}$ jego racjonalnym określeniu. Jednak rolę racjonalnego określenia można by tu podać $\mathrm{w}$ wątpliwość. Cóż mi z tego, iż znam wysokość górskiego szczytu, znam skałę, która się nań składa? Posiadam wiedzę, która pozwala mi określić z wielką dokładnością właściwości monumentalnej góry. Nie czuję się z tym pewniej w sytuacji, gdy owa góra rozpościera przede mną swe krańce, milcząc w swej wiekowości. Powiedzieć, że mnie zachwyca, to znacznie więcej. Wsłuchać się w owe milczenie, zdobyć szczyt i spojrzeć zeń na rozległe przestrzenie ułożone u jego stóp. Zdobyć górę, jak powie alpinista, to ją poznać. Wszak poznanie to ma zupełnie inny charakter, niż opis noszący znamiona wiedzy. Nie sposób zauważyć dziwnej więzi, jaka tworzy się między człowiekiem a miejscem, z którego tajemnicą obcował. Tak, jak nie sposób zaprzeczyć, ile z tajemnic, które kryją w sobie wspaniałe tereny starożytnych miast, ale i na pozór zwykłe miejsca, stało się inspiracją dla poetów. Dostrzeżenie tajemnicy zdaje się pochłaniać całą uwagę podmiotu. Możemy się zastanawiać, czy dostrzeżenie to nie zamienia jej siedliska w swoistego idola. Nawet wówczas przepaść między człowiekiem a światem jest nieredukowalna. Jednak-

\footnotetext{
5 Tamże, s. 19.
} 
że zatrzymajmy się $w$ miejscu, gdzie tajemnica pozostała nierozpoznana, a rzeczywistość na ludzkie pragnienie jedności odpowiada milczeniem. Swoboda w świecie, który stał się obcy, oto czemu wolność może przerażać.

Ten moment być może tkwi u podłoża owej ucieczki od wolności. Tego, że ludzie odpychają od siebie wolność, rezygnują z niej, a nawet, by tak rzec, zaprzedają ją. Pozbycie się ciężaru wolności wydaje się im łatwiejszym rozwiązaniem. Trudno jednak jednoznacznie ocenić, czy jest tak w istocie. Jeśli bowiem ograniczę swą wolność obcą władzą, na którą sam się godzę, zdaję się na jej wiedzę i rozsądek. Gdy jednak ta władza okaże się nieudolna, a mnie z jej przyczyny przyjdzie żyć w ciężkich warunkach, okaże się, iż wolność do mnie powróci. Ostatecznie troska, którą darzę swoje życie, wymusi na mnie działanie świadome i wolne, nierzadko przepojone buntem. Przyjęcie uśpienia świadomości, a więc swoiste trwanie w letargu, jakim jest przyjęcie uśpienia świadomości, dotyczy tych, którzy oddalili się od życia jako interakcji ze światem. Ten motyw refleksji Camusa może być kojarzony z sytuacjami granicznymi u Jaspersa. Pozostają oni w tym stanie tak długo, jak świat ten nie wymusza od nich działania. Gdy rzeczywistość ostatecznie wymusza ruch świadomości, może on być chwilowy lub stały. Pierwszy przypadek nie jest zjawiskiem nikomu obcym. Są chwile, gdy rozpoznajemy koniec lub początek jakiegoś etapu życia. Wtedy pojawia się refleksja. Cała nasza dotychczasowa egzystencja jawi się jako film. Doskonale rozpoznajemy obrazy, sytuacje, im jednak mniej świadomej postawy im towarzyszyło, tym bardziej nasza postać przypomina aktora, sama zaś akcja tych wspomnień nie tak wyrazista, jak byśmy tego pragnęli. 
Rafał Materek - Wolność absurdalna a odpowiedzialność...

\section{Wolność od odpowiedzialności}

Podstawowym powodem ucieczki przed podjęciem wolności pozostaje chęć uzyskania swobody innego rodzaju. Jak już zauważyliśmy, człowieka, który unika ruchu świadomości, charakteryzują pewne pojęcia, jak na przykład wspomniana właśnie ucieczka. Ich osobliwość w tym przypadku polega na pasywności, jaką się odznaczają. Nie inaczej jest z rodzajem wolności, która wydaje się atrakcyjna dla współczesnego człowieka. Wolność od odpowiedzialności. Poświęcono jej już niezliczoną ilość tekstów. Problem przewijający się od czasów społeczeństwa zindustrializowanego, bardzo silnie poruszany przez przedstawicieli szczególnie szkoły frankfurckiej, jak np. M. Horkheimer6 czy E. Fromm ${ }^{7}$, ale będący jednocześnie kluczowym punktem rozważań J. P. Sartre'a czy właśnie A. Camusa. Ciężar odpowiedzialności za ów stan uśpienia świadomości odnoszony był do politycznych wymiarów świata, społecznych przemian, a także samej natury człowieka. Camus nie rozważa tego problemu ze względu na zewnętrzne uwarunkowania. Faktem jest pewien stan, należy się z nim rozprawić, zamiast szukać winnych.

Dlaczego wolność od odpowiedzialności jest tak bardzo pożądana? Pytanie kryje w sobie na pozór prostą odpowiedź. Oczywistym jest wszak, iż najbardziej pożądane jest to, czego posiada się mało, a jest trudne do zdobycia. Dla wielu osób takim dobrem jest spokój. Najprostszą zaś drogą ku niemu wycofanie. Nieangażowanie się w jakiekolwiek życie publiczne, unikanie działania, a nawet wydawania sądów, to cechy coraz popularniejsze w społeczeństwie, które straciło wiarę w jakąkolwiek zmianę. Co więcej, odnosi się ono do zmiany nieufnie i z dystansem, jak do wszystkiego, co oznaczać może nowe, nieznane. Niechęć do powzięcia działania, „lenistwo”, jak to ujął Levinas w „Istniejący i Istnienie”, błyskawicznie ogarnia całość aspektów ludzkiej egzystencji. Słusznie zauważa on jednak, że: „o ile nie jest to stan

\footnotetext{
${ }^{6}$ M. Horkheimer, Społeczna funkcja filozofii, [w:] Tenże, Społeczna funkcja filozofii. Wybór pism, Warszawa 1987.

7 E. Fromm, Mieć czy być, Poznań 1997.
} 
snu lub senności, to nie ma on nic wspólnego ze spokojem"8. Powołanie do działania jest uczuciem niezbywalnym. Stąd też potrzeba złej wiary. Levinas w tej pracy mówi o pewnej ogólnej kondycji ludzkiej. Jednak w tym konkretnym przypadku, jaki tu omawiam, jego słowa doskonale rozjaśniają sytuację człowieka, który - jak by to ujął Heidegger - pogrążony jest w się. Człowiek ten doskonale zdaje sobie sprawę, iż nie jest to naturalny porządek rzeczy, prowadzi nieustanną walkę mimo najszczerszych chęci jej zaprzestania. Walka ta, odbywająca się między chęcią poszukiwania i działania a wygodną bezczynnością, nie zna innego wyniku, jak ostateczny ruch świadomości. W innym przypadku zawsze pozostanie nierozstrzygnięta. Nawet śmierć nie przynosi rozwiązania. Kończy jedynie ową walkę remisem.

W powyższych rozważaniach dotyczących lęku przed odpowiedzialnością i jego podstaw odwoływałem się do społecznych obserwacji i kontekstów. Jak można by jednak przyjrzeć się tej kwestii w jej filozoficznym ujęciu? Odpowiedzialność dotyczy wyborów. Wybór zaś to pojęcie właściwe wolności. Lęk więc ten w najbardziej bezpośredni sposób można ująć jako lęk przed wolnością. Idąc dalej, powiedzieć można, że to lęk przed życiem. Wskazać na swoje życie, to wskazać właśnie na pewne wybory. Mówi się, że czyjeś życie do niego należy. Przynależność to jednak niewystarczająca właściwość dla ukonstytuowania życia.

Posiadając pewna sumę pieniędzy i oddając je do banku z nadzieją, iż odpowiedni ludzie je pomnożą, postępuję na pozór rozsądnie. Z takiego samego założenia wychodzą osoby, które oddają decyzje dotyczące swojego życia innym ludziom bądź schematom, jakie ci drudzy stworzyli. W obu przypadkach padamy ofiarą tego samego przeświadczenia, jakoby osobom trzecim, jakim powierzamy swoje dobro, zależało przede wszystkim na naszej pomyślności. Jednak nasze powodzenie jest jedynie efektem ubocznym. W obu przypadkach zasilamy jedynie system, skuszeni pomniejszymi korzyściami, jakie z tego tytułu nam przypadną. 0 ile do wartości materialnych, takich jak pienią-

\footnotetext{
8 E. Levinas, Istniejący i istnienie, Kraków 2006, s. 36.
} 
Rafał Materek - Wolność absurdalna a odpowiedzialność...

dze, można mieć różny stosunek, o tyle kwestia życia jest sprawą, której powaga nie pozostawia złudzeń.

Przezwyciężając zatem lęk, przyjrzyjmy się wolności absurdalnej, jaką proponuje Camus. Wspiera się ona na konflikcie. Nie jest to żaden nowy konflikt, lecz cały czas ten sam rozdźwięk między światem a umysłem. Nośnikiem i wyrazem tego rozdźwięku jest świadomość. Jak widać więc, jej rola sięga dalece głębiej w podstawę możliwości wolności, niż można by sądzić. To już nie tylko świadomy charakter przeżywanych chwil jest jej zdobyczą, lecz polemika z potrzebą sensu. W tym właśnie momencie, gdy źródłem napięcia uczynimy świadomość, zawieszoną między światem a umysłem, wkroczymy nie tylko na obszar dyskursu o wolności, lecz także przestrzeni możliwego sensu lub jego braku. Pasywne odniesienie do świata prowadzi do uzależnienia od świata, zaś wolność sprzyja tworzeniu swej niezależności.

\section{Wolność i odpowiedzialność}

Odpowiedzialność jest nierozerwalnie złączona z wolnością pozytywną. Możliwość dokonywania wyborów wiąże się z wzięciem na siebie konsekwencji ich wyników. To pewna oczywistość, lecz dodajmy do tego zadanie kreowania świata, jakie wiąże się z wolnością pozytywną. W tym wypadku jeszcze bardziej widać trudność zadania, jakim jest powzięcie wolności absurdalnej. Gdy kreujemy świat wokół siebie, wpływamy na rzeczywistość, cały czas aktywna jest świadomość przypominająca o jego obcości. To wszystko, co jest wokół nas, staje się jedynie elementem działań, kiedy wkraczamy weń jako twórca, nie zaś jako odtwórca pewnej roli. I choć Heraklit rzecze: Aion, pais esti paizon, pesseuon; paidos he basileie ${ }^{9}$, zdobycie się na dystans wobec własnego życia jest bardzo trudnym zadaniem.

Albert Camus w swojej koncepcji pozostawia wybór. Stanem pierwotnym jest poczucie niewinności. Może ono towarzyszyć człowie-

\footnotetext{
${ }^{9}$ G. Wohlfart, „Also sprachHerakleitos”. Heraklits Fragment B 52 und NietzschesHeraklit-Rezeption, München 1991, s. 39.
} 
kowi niezależnie od powziętych zadań, może też ustąpić poczuciu odpowiedzialności. Ten wybór odróżnia znacznie wizję Camusa od sytuacji, na jaką skazuje człowieka J. P. Sartre. Jest to wizja odpowiedzialności koniecznej, związanej z samym istnieniem w świecie. Trudno orzec, która z koncepcji trafniej obrazuje problem odpowiedzialności w kontekście odczuć, jakie towarzyszą człowiekowi w trakcie jego egzystencji. Niejednokrotnie czujemy się odpowiedzialni za tę najbliższą cząstkę świata wokół nas, jednak nie mniej jest chwil, gdy wobec ogromu zdarzeń czujemy się jedynie trybem pewnej maszyny, obdarci z jakiejkolwiek sprawczej mocy. Można powiedzieć, że relacja między tymi dwoma spojrzeniami na problem odpowiedzialności obrazuje rozterkę samego człowieka. Sukces, jaki udaje się osiągnąć za sprawą zwrócenia się ku działaniu, skłania nas do poszerzania jego zakresu, a przez to do odkrywania swojej odpowiedzialności jako czegoś pierwotnego. Ogrom zdarzeń niezależnych od nas, a mających ważny wpływ na nasze życie, może działać wprost odwrotnie. Nie rozstrzygałbym zatem samej kwestii niewinności człowieka u Camusa jako propozycji niebezpiecznej. Jak widać, wymaga ona być może nieco mniej ostrego, a bardziej subtelnego rozpatrzenia.

Można także domniemywać, że w przypadku koncepcji Camusa odpowiedzialność wynikająca z wolności może wręcz stać się niejako darem. Natrafiamy tu na pewną furtkę, prowadzącą nas na skraj świata absurdalnego, jednocześnie wracając do korzeni myśli egzystencjalnej. Zwrot ku wolności pozytywnej, stanie się twórcą, sprawia, że człowiek wykracza poza, niż określałby to bunt scharakteryzowany przez Camusa. Wejście w relację z odpowiedzialnością to element wymykający się egzystencjalnemu tu i teraz. Ta konsekwencja oznacza pozostawienie śladu mającego charakter ciągły. Są to już jednak rozważania na pograniczu koncepcji Camusa i Nietschego. Pozwalam sobie na nie z uwagi na inspirację, jaką czerpał Camus z myśli niemieckiego filozofa życia. 
Rafał Materek - Wolność absurdalna a odpowiedzialność...

\section{Problem relatywizmu moralnego}

Problem odpowiedzialności u Camusa wiąże się z kwestią relatywizmu moralnego. To jeden z podstawowych zarzutów wobec koncepcji wolności absurdalnej. Niewinność człowieka, powoływanie własnych wartości oraz ich nietrwały charakter są tymi cechami myśli Camusa, które mogą wzbudzać niepokój moralny. Sam autor wspomina o problemie zła, jednak dla niniejszych rozważań przede wszystkim należy dokładniej przyjrzeć się podstawom jego myśli. Jednym z podstawowych zagadnień jest świadomość. Ciągle odnawiająca się, „przerywista”, charakterystyczna dla tego, kto zwrócił się ku wolności pozytywnej. Świadomość, jako napięcie między pragnącym zrozumienia człowiekiem i milczącym światem. Ta przytłaczająca relacja prowadziłaby do rezygnacji człowieka, gdyby nie bunt. Gdzie i jak umieścić tu relacje międzyludzkie?

Wracam jeszcze raz do pojęcia niewinności. Owo pojęcie wskazuje na umieszczenie człowieka poza dobrem i złem. Bez balastu kultury człowiek nie jest w stanie teoretyzować zła czy też dobra. Miejsce, gdzie napotyka na tę problematykę, to spotkanie z drugim człowiekiem. Jego radość i cierpienie otwierają zupełnie nową przestrzeń świadomości. One są źródłem pojęcia dobra i zła, choć wcześniej znał te uczucia z własnego doświadczenia. Różnicą jest jednak typ relacji. Relacja między dwojgiem ludzi nie jest obciążona tymi samymi konsekwencjami, co relacja człowieka ze światem. Co więcej, wobec tej drugiej relacji człowiek rozpoznaje $\mathrm{w}$ drugiej osobie towarzysza dzielącego te same niepokoje. Moment spotkania to przebudzenie nowej świadomości. Moja niewinność wobec świata pozostała nienaruszona, pojawiła się natomiast odpowiedzialność za drugiego człowieka. Czy jest ona konieczna? Z racji jej przynależności nie jest. Można unikać tego typu relacji. Dzieje się tak często, gdy świadomość jest uśpiona. Wtedy powolne uleganie rutynie i pozbawienie egzystencji swego ciężaru wpędza w swoisty letarg, a drugi człowiek staje się zaledwie

elementem świata i podlega właściwemu takiemu stanowi rzeczy rodzajowi relacji. Widać w tym miejscu, jak bardzo znajdujemy się na- 
dal w obrębie Camusowskiej koncepcji. Tylko przebudzona i aktywna świadomość dostrzega wagę obu wcześniej wspomnianych relacji.

\section{Pustka}

W obrębie relacji między ludźmi chciałbym wskazać motyw pustki. Charakteryzuje ona każdego człowieka jako istotę transcendentalną. Nasza potencjalność wypełniona jest pustką. Nieodłącznie towarzyszy nam możliwość kroku w nieznane, czujemy również owo nieznane. Jesteśmy świadomi tego obszaru niezależnie od tego, czy decydujemy się na jakikolwiek krok. Myśl, jaka wiąże się z tym odczuciem, nierzadko staje się ciężarem, od którego człowiek za wszelką cenę chce uciec. Wszak przepaść między nami a światem zdaje się być dalece bardziej uzasadniona, niżeli jakiekolwiek rozdarcie w samej materii naszej świadomości. Znamy zasadę działania wobec obcego nam świata - to nasze usilne próby zrozumienia go, uczynienia posłusznym naszym kategoriom i pojęciom. Problematyczne natomiast jest dla nas ustalenie działania wobec faktu, iż nigdy - póki żyjemy - nie sposób ująć nas w sposób kompletny. Pustka, jako obszar, z którego wyłaniają się możliwości, jest siedliskiem pytań. Nasze działanie może być próbą odpowiedzi na nie, może też generować nowe pytania. Jednak częściej decydujemy się na ucieczkę od owych pytań i w tym miejscu pojawia się drugi człowiek.

Drugi człowiek wypełnia naszą pustkę, zagarniając pełnię naszej uwagi. Ta sztuczka udaje się tak długo, jak tylko pozwala na to utrzymująca ją relacja. Zainteresowanie drugą osobą, znalezienie w niej jakiejś cząstki istoty człowieczeństwa na chwilę oddala nas od całej obcości, z jaką przyszło nam się mierzyć. Czujemy się bezpieczniej. Jednak nadal to tylko sprytna sztuczka. Pustka w żaden sposób nie została wypełniona, jedynie świadomość została przeprogramowana na odbieranie informacji z innego źródła. Gdy druga osoba umyka naszemu polu widzenia i polu myślenia, zostajemy ponownie sami ze sobą. 
Rafał Materek - Wolność absurdalna a odpowiedzialność...

Zdecydowałem się przytoczyć motyw pustki ze względu na niebezpieczeństwo, na jakie on wskazuje. Związane jest ono tak z utratą wolności, jak i odpowiedzialności. Jeśli bowiem relacja z drugim człowiekiem staje się sposobem na ucieczkę od świadomości własnej transcendentalności, jest zarazem ucieczką od wolności. Jakże mówić tu także o odpowiedzialności za drugą osobę, gdy kierują nami pobudki stricte egocentryczne. Dopiero stan pogodzenia się z własną pustką daje możliwość prawdziwego wyjścia ku drugiemu człowiekowi. Nie pozwolić, by ilość niezapisanych kart życia owocowała lękiem przed tym, kim jesteśmy, nie uciekać przed fundamentalnymi pytaniami dotyczącymi nas samych, oto warunki możliwości pełnej wolności. To moment, w którym druga osoba może stać się swoistym drogowskazem, źródłem wielu odpowiedzi, których próżno byłoby szukać w nas samych. To zarazem moment, w którym kolejny raz ujawnia się wielka odpowiedzialność związana z relacją człowieka do człowieka.

\section{Podsumowanie}

W koncepcji Camusa wolność absurdalna jest odpowiednikiem wolności pozytywnej, z jaką mamy do czynienia choćby u Nietzschego. Jest to działanie w takim samym stopniu zwrócone ku kreowaniu rzeczywistości, wzbogacone w stosunku do poprzednich koncepcji o motyw buntu. Na uwagę zasługuje swoisty sposób powiązania wolności z odpowiedzialnością. Choć wolność człowieka jest nieograniczona, odpowiedzialność dotyczy tylko świadomej relacji między osobami. Problem relatywizmu moralnego w tym przypadku rozwiązany zostaje poprzez motyw empatii, silny w filozofii Camusa od samego początku. Drugi człowiek staje się odbiciem nas samych wobec milczącego świata. Tak, jeśli tylko jesteśmy świadomi, stajemy się odpowiedzialni w swej niewinności. 


\section{Bibliografia:}

Camus Albert, Człowiek zbuntowany, Wyd. Muza, Warszawa 2002.

Camus Albert, Mit Syzyfa, Wyd. De Agostini, Warszawa 2001.

Fromm E., Mieć czy być, tłum. J. Karłowski, Dom Wydawniczy Rebis, Poznań 1997.

Heidegger M., Bycie i Czas, Wyd. PWN, Warszawa 2004.

Horkheimer M., Społeczna funkcja filozofii, tłum. J. Doktór, [w:] M. Horkheimer, Społeczna funkcja filozofii. Wybór pism, Wyd. PIW, Warszawa 1987.

Jaspers K., Filozofia egzystencji. Wybór pism, Wyd. PIW, Warszawa1990.

Jaspers K., O źródle i celu historii, Wyd. Marek Derewiecki, Kęty 2006.

Jaspers K., Rozum i egzystencja. Nietzsche a chrześcijaństwo, Wyd. PWN, Warszawa 1991.

Levinas E., Istniejący i istnienie, tłum. J. Margański, Wyd. Homini, Kraków 2006.

Wohlfart G., „Also sprachHerakleitos”. Heraklits Fragment B 52 und NietzschesHeraklit-Rezeption, Wyd. Karl Alber, München 1991. 